\title{
A trial of parent held child health records in the armed forces
}

\section{S A StJ Miller}

British Military Hospital, Rinteln, West Germany Lt Col S A StJ Miller, MB, specialist in community medicine (child health)

Br Med F 1990;300:1046
The strategy of issuing parents with the main record of their children's development was considered likely to benefit families in the armed forces because it would provide those who have to move home regularly with an up to date record of immunisation procedures and developmental checks. The scheme was therefore introduced in the British army and Royal Air Force garrisons in West Germany for a trial period. From October 1987 health visitors issued child health records to the parents of newborn babies, and the reliability of parents as custodians of these documents was tested by conducting a follow up study.

\section{Subjects, methods, and results}

A cohort of infants born in British service hospitals in West Germany during one calendar month was followed up for a year. The parents were issued with child health records published by Castlemead and designed to be held by parents and were interviewed six months later by their health visitor to ascertain whether they liked the scheme and had managed to keep the record safely. The proportion of first developmental examinations and immunisation prescriptions which had been completed on the document by the general practitioner was also determined. After 12 months health visitors once again checked the availability of the records, and parents were sent a questionnaire so that they could express their opinions about the scheme.

One hundred and thirty seven families were issued with child health records in November 1987. Six months later 105 families were still based in West Germany, 31 had moved back to the United Kingdom, and in one a cot death had occurred. None of the families still based in West Germany had lost the record, and 95 reported that they liked the scheme. The first developmental examination had been recorded in 99 cases and the immunisation prescription signed by the general practitioner in 102 . Only 17 of the 31 families no longer based in West Germany could be contacted, and 15 of these claimed that they still had the record. In the other two cases the record had been "confiscated" by civilian medical practitioners. The whereabouts of the record was therefore established in $123(90 \%)$ of the cohort and in none of these cases had the record been lost.

After 12 months only 88 families still remained in
West Germany. Health visitors were able to confirm that 85 of these still held the record. Three families could not be contacted. Sixty six (75\%) families still based in West Germany replied to a postal questionnaire and 63 said they approved of the scheme. The scheme was criticised by eight families. In most cases this was because medical professionals seemed to show a lack of interest in the records. Eleven families said they would have preferred a smaller record than the A4 size Castlemead version which was issued.

\section{Comment}

Parental reliability and willingness to participate are obviously key factors in the outcome of any scheme that depends on parents holding their children's health records. One recent study suggested that when child health booklets are issued to parents as an additional health record about $10 \%$ are lost within 12 months. ${ }^{1}$ More encouraging results were found in a south London study, however, ${ }^{2}$ and when 500 parents in Abingdon were entrusted with the only complete record of their child's development none were lost. ${ }^{3}$ Giving parents genuine responsibility for their children's health surveillance appears to be an important factor in the successful implementation of the scheme, and this was borne out by the reliability of parents in this study. Other factors that have been shown to be important include how well parents are instructed, ${ }^{4}$ how well organised and motivated the health visitors are, ${ }^{3}$ and how well the scheme is publicised among health professionals beforehand.' All these factors were taken into account when the scheme was tried in the military community.

It is now planned to issue parent held child health records for all babies born to families in the armed forces based in West Germany. The outcome of trials in Oxfordshire and the wider use of the scheme in the United Kingdom are eagerly awaited. The acceptance and general use of this system would undoubtedly help families in the armed forces, who are often without any form of medical documentation after moves to and from overseas postings. Many civilian families must move around almost as much and would also benefit from this aspect of the scheme.

I thank all health visitors working for the Soldiers', Sailors' and Airmen's Association in British Forces Germany, in particular Mrs Susan Ashdown, for help with this study.

1 O'Flaherty S, Jandera E, Llewellyn J, Wall M. Personal health records: an evaluation. Arch Dis Child 1987;62:1152-5.

Lakhani AD, Avery A, Gordon A, Tait N. Evaluation of a home based health record booklet. Arch Dis Child 1984;59:1076-81.

3 Saffin K. Parents as partners. Community Outlook 1986; Feb:21-2.

4 Pearson P. Parent-held records: what parents think. Health Visitor 1985;58 15-6.

(Accepted 6 February 1990
Department of Medicine City Hospital, Nottingham NG5 1PB

Judith R Glynn, MRCP, registrar

Elizabeth K Carr, PHD,

research sister

William J Jeffcoate, FRCP, consultant

Correspondence to:

Dr Glynn.

$\operatorname{BrMed}$ f 1990;300: 1046-7

\section{Foot ulcers in previously undiagnosed diabetes mellitus}

\author{
Judith R Glynn, Elizabeth K Carr, \\ William J Jeffcoate
}

Overall, $15 \%$ of diabetics develop foot ulcers, ${ }^{1}$ and the proportion increases with age. Much emphasis has been placed on preventing foot ulcers in those at risk, but such ulcers may be the presenting manifestation of diabetes. As foot ulcers are usually the result of neuropathy or vasculopathy, or both, patients with them may be expected to have other diabetic complications at the time of diagnosis. We determined the clinical characteristics of and the prevalence of complications in patients who presented with a foot lesion and were subsequently found to have diabetes.

\section{Patients, methods, and results}

From one physician's list we identified 39 patients with newly diagnosed diabetes who had had foot ulcers at the time of diagnosis, and we reviewed their case notes. We compared their clinical characteristics at the time of diagnosis with those of controls selected from the same list, who were matched for sex, age at the time of diagnosis (to within two years), and race (all were 
Characteristics of 39 patients who presented with foot ulcers and were found to have diabetes and of 39 diabetic controls matched for sex, age at diagnosis, and race. Values are numbers of patients except where stated otherwise

\begin{tabular}{|c|c|c|c|c|}
\hline & $\begin{array}{l}\text { Patients with } \\
\text { ulcers }\end{array}$ & Controls & $\mathrm{p}$ Value & $\begin{array}{c}\text { Relative risk } \\
(95 \% \text { confidence interval })\end{array}$ \\
\hline Men:women & $23: 16$ & 23:16 & & \\
\hline \multicolumn{5}{|l|}{ Age (years): } \\
\hline Range & $51-86$ & $51-85$ & & \\
\hline Mean & 67 & 67 & & \\
\hline Median & 65 & 66 & & \\
\hline \multicolumn{5}{|l|}{ History of smoking: } \\
\hline Within past five years & 18 & 10 & & \\
\hline More than five years previously & 8 & 17 & NS & \\
\hline Never & 13 & 12 & & \\
\hline $\begin{array}{l}\text { Family history of diabetes in } \\
\text { first degree relative }\end{array}$ & 9 & 9 & NS & \\
\hline Peripheral vascular disease ${ }^{\star}$ & 27 & 12 & $0 \cdot 041$ & $4.0(1.46$ to 13.6$)$ \\
\hline Men & $14 / 23$ & $8 / 23$ & NS & \\
\hline Women & $13 / 16$ & $4 / 16$ & 0.012 & $10 \cdot 0(1.42$ to 442$)$ \\
\hline Peripheral neuropathy $\dagger$ & 27 & 12 & 0.0026 & $4.75(1.58$ to 19.2$)$ \\
\hline Men & $18 / 23$ & $7 / 23$ & 0.0074 & $6.5(1.47$ to 59.5$)$ \\
\hline Women & $9 / 16$ & $5 / 16$ & NS & \\
\hline Retinopathy & $13 / 33$ & $2 / 33$ & $0 \cdot 0034$ & $12.0(1.78$ to 528$)$ \\
\hline Men & $10 / 23$ & $1 / 23$ & 0.0039 & \\
\hline Women & $3 / 10$ & $1 / 10$ & NS & \\
\hline Proliferative retinopathy & $2 / 33$ & $0 / 33$ & NS & \\
\hline Proteinuriał & $5 / 37$ & $3 / 37$ & NS & \\
\hline Creatinine $>120 \mu \mathrm{mol} / \mathrm{I}$ & $5 / 34$ & $6 / 34$ & NS & \\
\hline Hypertension $\$$ & 7 & 18 & 0.013 & $0.214(0.0395$ to 0.768$)$ \\
\hline Ischaemic heart disease & 7 & 8 & NS & \\
\hline Stroke & 2 & 2 & NS & \\
\hline
\end{tabular}

* One or more foot pulses absent (dorsalis pedis or posterior tibial).

†One or more of absent ankle jerks, motor neuropathy, decreased sense of light touch, pin prick, or vibration. $\ddagger$ Dipstick testing showed more than "trace."

\$Previously diagnosed or diastolic blood pressure $>95 \mathrm{~mm} \mathrm{Hg}$ on at least two occasions.
f Previously diagnosed or evident on electrocardiography.

white). The comparisons between the groups were analysed with the exact test based on the binomial distribution.

The table gives the patients' clinical characteristics. All had non-insulin dependent diabetes. Of the patients with ulcers, 27 were judged to have predominantly vascular lesions, five predominantly neuropathic lesions, five heel lesions, and two skin lesions. Peripheral vascular disease, peripheral neuropathy, and retinopathy were all significantly more common among the patients with ulcers than the controls. There was a significant relation between retinopathy and smoking among the patients with ulcers: only one of 11 patients who had never smoked had retinopathy, compared with 13 of 24 current and former smokers $(p<0.02$, Fisher's one tailed test; four patients were excluded because data were missing). No significant relation was found between smoking and the occurrence of foot ulcers or any other complication of diabetes.

\section{Comment}

Most studies of foot ulcers have included all diabetic patients with foot ulcers, and the mean duration of diabetes before ulceration developed has been 10-16 years. ${ }^{23}$ In these studies the association between ulceration and peripheral vascular disease, peripheral neuropathy, and retinopathy has been recognised..$^{2}$ Walsh et al described an "eye-foot" syndrome in new diabetics. ${ }^{4}$ They identified 47 patients with both a foot lesion and retinopathy among 6451 patients with newly diagnosed diabetes. A further 370 patients had retinopathy without a foot lesion, but no corresponding figure was given for those with foot lesions alone.

We confirmed the association between ulceration and the two factors that are most likely to have contributed to its formation - namely, peripheral vascular disease and peripheral neuropathy. We also found a strong association with retinopathy. Nearly half of the controls had hypertension, which suggests that their diabetes may have been discovered during routine management of their blood pressure. The high prevalence of hypertension among the controls may explain the similar prevalence of proteinuria and raised creatinine concentration in the two groups.

Smoking has been associated with foot lesions in some studies ${ }^{3}$ but not others. ${ }^{2}$ It has also sometimes been associated with retinopathy. ${ }^{5}$ In this study retinopathy was significantly associated with smoking but ulceration, peripheral vascular disease, and neuropathy were not.

This study emphasises the need to look for further complications, particularly retinopathy, in diabetic patients presenting with foot ulcers. Such patients are not always seen in specialised units, and in many of them blood glucose concentrations are not particularly high and the diabetes is thought to be mild. In terms of complications, morbidity, and prognosis ${ }^{4}$ this is not the case. We suggest that all diabetic patients with foot ulcers should be referred to a specialist diabetic service for full evaluation.

We thank Rosamund Macfarlane, Sue Allen, and Elisabeth Fletcher for their help, and Professor Martin Gardner for statistical advice.

1 Levin ME, O'Neal LW, eds. The diabetic foot. 4th ed. St Louis: C V Mosby, 1988:ix-x.

2 Jones EW, Peacock I, McLain S, et al. A clinico-pathological study of diabetic foot ulcers. Diabetic Med 1987;4:475-9.

3 Delbridge L, Appleberg M, Reeve TS. Factors associated with development of foot lesions in the diabetic. Surgery 1983;93:78-82.

4 Walsh CH, Soler NG, FitzGerald MG, Malins JM. Association of foot lesions with retinopathy in patients with newly diagnosed diabetes. Lancet 1975 i: $878-80$.

5 Paetkau ME, Boyd TAS, Winship B, Grace M. Cigarette smoking and diabetic retinopathy. Diabetes 1977;26:46-9.

(Accepted 22 February 1990

\section{ONE HUNDRED YEARS AGO}

A full dress parade of all the troops in garrison was held at Poona on December 6th, to witness the presentation of the Victoria Cross to Surgeon Crimmin, Indian Medical Service. The ceremony was witnessed by a large crowd of spectators, among whom were the Duchess of Connaught and Mr. Childers. The troops were drawn up facing the west front line. H.R.H. the Duke of Connaught, accompanied by his staff, and Sir John Sterling Maxwell, the Hon. E. Willoughby, and Lieutenant Milner, Scots Guards, rode up at a quarter past eight, and the troops formed three sides of a square, the infantry being the base, the cavalry and artillery the wings. Surgeon Crimmin was then led up by Surgeon-General Webb, Indian Medical Service, followed by all the doctors in garrison, to the Duke of Connaught, who pinned the cross on his breast. After doing so H.R.H. the Duke of Connaught said: "Her Majesty the Queen has been pleased to confer on you the Order of the Victoria Cross. I have great pleasure in carrying out Her Majesty's commands. I most heartily congratulate you, Surgeon Crimmin, on the great honour that has been conferred on you, and on the great bravery displayed by you in devotion to your duty when serving with the 27 th Beloochis at the action near Lwekaw, in Eastern Karenni. This is the first time I have had the pleasure of presenting a Victoria Cross, and I need not say how greatly this is enhanced by giving it to an officer of the Bombay Army, who has so nobly carried out his arduous duties in the field, risking his life in attending the wounded under a heavy fire. May you live long to wear this much-coveted distinction, and to set an example of bravery and devotion to all who have the honour of serving the Queen and their country." The troops were then re-formed into line, and marched past, Surgeon Crimmin occupying a place by the side of the Duke at the saluting base.

(British Medical fournal 1890;i:33) 